\title{
PRÉPARATION DE SUSPENSIONS CONCENTRÉES ET CONGELÉES \\ DE BACTÉRIES LACTIQUES THERMOPHILES DESTINÉES A LA FROMAGERIE (1)
}

\author{
par \\ E. VALLES et G. MOCQUOT \\ Station Centrale de Recherches Laitières et de Technologie \\ des Produits Animaux, C.N.R.Z., Jouy-en-Josas (Yvelines)
}

L'utilisation de bactéries lactiques thermophiles (Lactobacillus helveticus et Streptococcus thermophilus), sous la forme de suspensions concentrées et congelées dans les fabrications traditionnelles de Gruyère a été décrite dans une publication précédente [1].

Le but du présent travail est de décrire le mode de préparation des suspensions concentrées congelées, ainsi que leurs principales caractéristiques. En outre, l'emploi pratique en fromagerie exigeant des préparations à prix de revient modéré, nous avons été conduits à étudier et à mettre au point un milieu de culture peu coûteux.

\section{Matériel et méthodes}

\section{1) Mise au point d'un milieu de culture à faible prix de revient.}

Après divers essais préliminaires ayant porté sur sept milieux différents, deux de ces milieux de culture, $\mathrm{A}$ et $\mathrm{B}$, ont été retenus.

$\begin{array}{lcc}\text { Poudre de lait }(a) \ldots \ldots \ldots \ldots \ldots \ldots & \text { Milieu } A & \text { Milieu } B \\ \text { "Corn steep " } \sec (b) \ldots \ldots \ldots \ldots \ldots \ldots & 50 \mathrm{~g} & 40 \mathrm{~g} \\ \text { Papaïne titre } 400(c) \ldots \ldots \ldots \ldots \ldots & -\ldots, 5 \mathrm{~g} & 15 \mathrm{~g} \\ \text { Extrait de levure }(d) \ldots \ldots \ldots \ldots \ldots & 5,0 \mathrm{~g} & 0,5 \mathrm{~g} \\ \mathrm{SO}_{4} \mathrm{Mn}, 2 \mathrm{H}_{2} \mathrm{O} \ldots \ldots \ldots \ldots \ldots \ldots \ldots & 0,12 \mathrm{~g} & 5,0 \mathrm{~g} \\ \text { Lactosérum de fromagerie }(e) \ldots \ldots & 1 \text { litre } & 0,12 \mathrm{~g}\end{array}$

(a) Poudre instantanée de lait écrémé, garantie sans antibiotiques, Elle-et-Vire, Condé-sur-Vire (Manche).

(b) Roquette Frères, Lille.

(c) Société Rapidase, Seclin (Nord).

(d) Type alimentaire, Fould Springer, Maisons-Alfort (Seine).

(e) Lactosérum de fromagerie de Gruyère, écrémé, utilisé aussitôt après fabrication du fromage ou conservé, pendant moins de 4 jours, entre 3 et $4^{\circ} \mathrm{C}$.

(1) Ce travail a bénéficié d'une subvention de la Délégation générale à la Recherche scientifique et technique (Contrat 65-FR-165). 
La préparation du milieu A commençait par la dissolution de la poudre de lait dans le lactosérum préalablement chauffé à $30^{\circ} \mathrm{C}$. Ensuite le mélange (à $p \mathrm{H} \mathrm{6,6-6,7)} \mathrm{était} \mathrm{porté} \mathrm{à} 65-70^{\circ} \mathrm{C}$ en $15 \mathrm{mn}$ (environ); la papaïne, préalablement délayée dans une petite quantité de mélange chaud, était alors ajoutée en agitant énergiquement et la température était maintenue entre 65 et $70^{\circ} \mathrm{C}$ pendant $10 \mathrm{mn}$. Ensuite, le mélange était porté, dans un temps compris entre 15 et $20 \mathrm{mn}$, à $90^{\circ} \mathrm{C}$ et maintenu entre 90 et $95^{\circ} \mathrm{C}$ pendant $10 \mathrm{mn}$. L'extrait de levvre était alors ajouté et ensuite le sulfate de manganèse ( $1 \mathrm{ml}$ d'une solution aqueuse à 12 p. 100 par 1 de milieu). Le milieu était clarifié à chaud $\left(50-60^{\circ} \mathrm{C}\right)$ en le faisant passer dans une centrifugeuse Sharples (type T IP, autoclave) à une vitesse que nous avons fait varier suivant les essais, entre 25 et $50000 \mathrm{t} / \mathrm{mn}$ (16 et $62000 \mathrm{~g}$ ) avec un débit d'environ $8 \mathrm{l} / \mathrm{h}$.

La préparation du milieu B commençait par la dissolution du "corn steep " dans le lactosérum, le $p H$ du mélange était ajusté entre 6,6 et 7,0 avec une solution concentrée de soude (D $=1,33$ ). Pour le reste, la technique de préparation était exactement la même que celle utilisée pour le milieu A.

Dans le cas des cultures à $p H$ constant, le milieu était stérilisé à l'autoclave à $115^{\circ} \mathrm{C}$ pendant 15 minutes et le $p \mathrm{H}$ après stérilisation était compris entre 6,0 et 6,3 .

Dans le cas des cultures classiques, aussitôt après le chauffage à $90-95{ }^{\circ} \mathrm{C}$ le milieu était refroidi à $50^{\circ} \mathrm{C}$ et ajusté à $p H \quad 6,8-7,0$. Dans ces conditions le $p \mathrm{H}$ après stérilisation à $115^{\circ} \mathrm{C}$ pendant 15 minutes était compris entre 6,6 et 6,7 .

\section{2) Souches.}

Elles appartenaient à la collection du C.N.R.Z. et étaient conservées à $-30^{\circ} \mathrm{C}$ dans du lait écrémé autoclavé.

Streptococcus thermophilus : $21,160,302$, SCH.

Lactobacillus helveticus : $\mathbf{3 0 3}$.

\section{3) Préparation des suspensions concentrées congelées.}

Le mode de préparation des suspensions concentrées et congelées de bactéries lactiques thermophiles était analogue à celui utilisé par Lamprech et Foster (2) pour les streptocoques mésophiles : dans un milieu convenable et à un $p H$ approprié on préparait des cultures riches en germes; on séparait les cellules bactériennes par centrifugation et on les plaçait dans un milieu idoine; ces suspensions étaient alors congelées puis conservées à basse température. 
TABLEAU I ENSEMBLE DES OPÉRATIONS CONDUISANT A L'OBTENTION DE SUSPENSIONS
CONCENTRÉES ET CONGELÉES DE BACTÉRIES LACTIQUES THERMOPHILES

\begin{tabular}{|c|c|c|c|}
\hline \multirow{2}{*}{$\begin{array}{l}\text { A partir d'une souche conservée } \\
\text { congelée dans du lait autoclavé }\end{array}$} & \multirow{2}{*}{$\begin{array}{l}\text { A partir d'une suspension } \\
\text { concentrée et congelée }\end{array}$} & \multicolumn{2}{|c|}{$\begin{array}{c}\text { Durée de chaque opération (a) } \\
\text { (en heures) }\end{array}$} \\
\hline & & $\begin{array}{l}\text { L. helve- } \\
\text { ticus } 303\end{array}$ & $\begin{array}{l}\text { Str. thermo- } \\
\text { philus } 302\end{array}$ \\
\hline $\begin{array}{l}\text { Décongélation rapide et incuba- } \\
\operatorname{tion}(b)\end{array}$ & 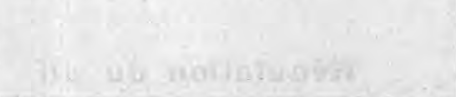 & $12-16$ & $12-16$ \\
\hline $\begin{array}{l}\text { Ensemencement à } 1 \text { p. } 100 \text { du } \\
\text { milieu }(c) \text { et incubation }\end{array}$ & & $12-16$ & $12-16$ \\
\hline $\begin{array}{l}\text { Ensemencement du milieu }(c) \text { ̀̀ } \\
5 \text { p. } 100 \text { et culture } \grave{a} p H \text { cons- } \\
\text { tant }(d)\end{array}$ & $\begin{array}{l}\text { Décongélation rapide de la sus- } \\
\text { pension, ensemencement du } \\
\text { milieu }(c) \text { à } 0,1 \text { p. } 100 \text { et cul- } \\
\text { ture à pH constant }(d)\end{array}$ & $12-16$ & $4-6$ \\
\hline Refroidissement de la culture & & 0,25 & 0,25 \\
\hline Conservation de la culture refroic & ie avant centrifugation & $1-2$ & $1-2$ \\
\hline Centrifugation à $50000 \mathrm{t} / \mathrm{m}(62$ & $00 \mathrm{~g})$ & 0,7 & 0,7 \\
\hline $\begin{array}{l}\text { Extraction du sédiment bactéri } \\
\text { concentrée et conditionnement }\end{array}$ & , préparation de la suspension & $0,25-0,5$ & $0,25-0,5$ \\
\hline Congélation à $-30^{\circ} \mathrm{C}$ & & & \\
\hline
\end{tabular}

(a) Toutes les durées correspondent aux temps moyens observés pour la préparation des suspensions concentrées à partir de 41 de milieu de culture.

(b) Les décongélations et les incubations étaient faites dans des bains-marie réglés à 370 C.

(c) Milieu de culture A ou B pour L. helveticus et A pour Str. thermophilus.

(d) $p \mathrm{H}$ de 5,0 ou 6,0 pour $L$. helveticus et 6,5 pour Str. thermophilus. 


\section{Mode opératoire.}

Des récipients de capacités variables étaient utilisés lors de la stérilisation du milieu et pendant la culture proprement dite. Pour des cultures de 2,5 à 41 , on a utilisé des flacons Pyrex eylindriques de 3 et $5 \mathrm{l}$, munis de bouchons permettant l'introduction de l'électrode, l'arrivée de la soude, l'ensemencement et la prise d'échantillon. L'agitation du milieu était assurée par un agitateur magnétique.

Pour les cultures de 14 à 161 , on a utilisé un fermenteur de 201 en acier inoxydable, muni d'un agitateur mécanique, immergé (comme les flacons) dans un bain-marie permettant l'incubation des cultures à la température choisie $\left(37^{\circ} \mathrm{C} \pm 0,5^{\circ} \mathrm{C}\right)$. Un bainmarie réglé à $3^{\circ} \mathrm{C} \pm 0,5^{\circ} \mathrm{C}$ était utilisé pour le refroidissement des cultures.

\section{Régulation du $p \mathrm{H}$.}

Elle était obtenue par addition automatique de la solution neutralisante $(\mathrm{NaOH}, 5 \mathrm{~N})$, avec agitation, à l'aide d'un $p$ Hmètre, régulateur-enregistreur Metrohm modèle E 368 et d'une vanne électro-magnéitque résistante à la soude. Précision de la régulation : $\pm 0,1 p \mathrm{H}[3,4]$.

Les conditions utilisées pour la préparation de suspensions concentrées congelées de bactéries lactiques thermophiles sont indiquées en détail dans le tableau I.. Pour cette préparation, on peut, soit partir d'une souche conservée congelée dans le lait écrémé, soit partir d'une suspension concentrée congelée. Dans les deux cas, la préparation des suspensions concentrées congelées comporte d'abord la culture des bactéries lactiques à $p H$ constant. Ces cultures sont ensemencées fortement afin de raceourcir leur phase de latence et ceci est obtenu grâce aux inoculums indiqués sur le tableau I : 5 p. 100 dans le cas d'une pré-culture et 0,1 p. 100 dans le cas d'une suspension concentrée congelée. Dans l'un et l'autre cas, nous avons vérifié que le nombre de germes apportés par l'inoculum était pratiquement identique.

La croissance de ces eultures était contrôlée en suivant les quantités de soude consommées par heure pendant l'incubation (tableaux II et III). Cette croissance était arrêtée par immersion des récipients dans le bain-marie réglé à $3^{\circ} \mathrm{C}, 1$ ou $2 \mathrm{~h}$ après que la consommation horaire de soude ait commencé à diminuer. La température du liquide contenu dans les récipients était ainsi ramenée de $37^{\circ} \mathrm{C}$ à $10^{\circ} \mathrm{C}$ en moins de $15 \mathrm{mn}$. La consommation totale de soude pendant toute l'incubation était alors notée.

On a observé que la valeur de ce paramètre (consommation totale de soude) restait pratiquement constante pour une souche donnée, toutes les conditions de culture étant semblables. De ce fait, lorsque cette valeur avait été déterminée pour une souche, les cultures successives de cette souche étaient arrêtées dès que la 
valeur en question était atteinte. Ceci demandait 4 à $6 \mathrm{~h}$ d'incubation pour les diverses souches de Str.thermophilus et de 12 à $16 \mathrm{~h}$ pour la souche 303 de $L$. helveticus.

TABLEAU II

Evolution D'Une culture a $p$ H constant de $L$. helveticus 303

\begin{tabular}{|c|c|c|c|c|}
\hline $\begin{array}{l}\text { Incu- } \\
\text { bation } \\
\text { (heures) }\end{array}$ & $\begin{array}{c}\text { Volume total } \\
\text { de NaOH } 5 N \\
\text { ajouté } \\
(\mathrm{ml})\end{array}$ & $\begin{array}{c}\text { Volume de NaOH } 5 \mathrm{~N} \\
\text { consommé d l'heure } \\
(\mathrm{ml})\end{array}$ & $p \mathrm{H}$ & $\begin{array}{c}\text { Quantité } \\
\text { de lactate de sodium } \\
\text { présent } \\
\text { dans la culture } \\
(\mathrm{g} / \mathrm{l})\end{array}$ \\
\hline $0 \ldots \ldots$ & 0 & 0 & 6,3 & 0,0 \\
\hline $1 \ldots \ldots$ & 0 & 0 & - & 0,0 \\
\hline $2 \ldots \ldots$ & 0 & 0 & - & 0,0 \\
\hline $3 \ldots \ldots$ & 3 & 3 & 5,0 & 0,4 \\
\hline $4 \ldots \ldots$ & 21 & 18 & 5,0 & 2,9 \\
\hline $5 \ldots \ldots$ & 58 & 37 & 5,0 & 8,0 \\
\hline $6 \ldots$ & 100 & 42 & 5,0 & 13,6 \\
\hline $7 \ldots \ldots$ & 153 & 53 & 5,0 & 20,6 \\
\hline $8 \ldots \ldots$ & 211 & 58 & 5,0 & 28,0 \\
\hline $9 \ldots \ldots$ & 272 & 61 & 5,0 & 35,6 \\
\hline $10 \ldots \ldots$ & 333 & 61 & 5,0 & 43,0 \\
\hline $11 \ldots \ldots$ & 394 & 61 & 5,0 & 50,2 \\
\hline $12 \ldots \ldots$ & 447 & 53 & 5,0 & 56,2 \\
\hline $13 \ldots \ldots$ & 500 & 53 & 5,0 & 62,2 \\
\hline $14 \ldots \ldots$ & 548 & 48 & $6,0^{*}$ & 67,4 \\
\hline
\end{tabular}

Conditions de culture

Milieu de culture, B. Volume initial, 41.

Température d'incubation : $37^{\circ} \mathrm{C}$.

Ensemencement : $5 \%$ avec une préculture préparée dans le même milieu $(p H$ initial 6,7$)$ après $16 \mathrm{~h}$ d'incubation.

Le $p \mathrm{H}$ des cultures était enregistré pendant toute la durée d'incubation, permettant ainsi de contrôler le bon fonctionnement du système de régulation du $p \mathrm{H}$.

Les cultures de lactobacilles effectuées à des $p H$ au-dessous de 6,0 étaient ajustées à $p \mathrm{H} 6,0$ en fin d'incubation.

Les cultures refroidies étaient centrifugées aseptiquement au moyen de la centrifugeuse Sharples préalablement stérilisée. Cette centrifugeuse était munie d'un groupe frigorifique assurant la réfrigération du bol et maintenant la température des liquides à l'intérieur du bol entre 6 et $10^{\circ} \mathrm{C}$, à des vitesses variant selon les essais entre 25000 et $50000 \mathrm{t} / \mathrm{mn}$ (correspondant respectivement à 16000 et $62000 \mathrm{~g}$ ), à un débit d'environ 6 à $7 \mathrm{1} / \mathrm{h}$.

* A la $14^{\text {e }}$ heure, la culture était ajustée à $p H$ 6,0 . 
TABLEAU III

Evolution D'Une culture a $p$ H constant de Str. thermophilus 302

\begin{tabular}{|c|c|c|c|c|}
\hline $\begin{array}{l}\text { Incu- } \\
\text { bation } \\
\text { (heures) }\end{array}$ & $\begin{array}{l}\text { Volume total } \\
\text { de NaOH } 5 \mathrm{~N} \\
\text { ajouté } \\
(\mathrm{ml})\end{array}$ & $\begin{array}{l}\text { Volume de NaOH } 5 \mathrm{~N} \\
\text { consommé à l'heure } \\
(\mathrm{ml})\end{array}$ & $p \mathbf{H}$ & $\begin{array}{c}\text { Quantité } \\
\text { de lactate de sodium } \\
\text { présent } \\
\text { dans la culture } \\
(\mathrm{g} / \mathrm{l})\end{array}$ \\
\hline $0 \ldots \ldots$ & 0 & 0 & 6.5 & 0,0 \\
\hline $1 \ldots \ldots$ & 20 & 20 & 6,5 & 2,7 \\
\hline $2 \ldots \ldots$ & 45 & 25 & 6,5 & 6,2 \\
\hline $3 \ldots \ldots$ & 145 & 100 & 6,5 & 19,5 \\
\hline ..... & 275 & 130 & 6,5 & 36,0 \\
\hline 5 & 300 & 35 & 6,5 & 39,0 \\
\hline 6 & 325 & 25 & 6,5 & 42,0 \\
\hline
\end{tabular}

Conditions de eulture

Milieu de culture, A. Volume initial, 41.

Température d'incubation : $37^{\circ} \mathrm{C}$.

Ensemencement : $0,1 \%$ avec une suspension concentrée et congelée.

La quantité de sédiment bactérien obtenue à partir d'un volume de milieu donné est restée la même quelle que soit la vitesse de rotation de la centrifugeuse à l'intérieur de l'intervalle indiqué.

Aussitôt la centrifugation terminée, le sédiment bactérien était extrait dv bol de la centrifugeuse, sous une hotte stérilisée par les rayons ultra-violets, et pesé. Puis, dans le cas des souches de Str. thermophilus, le sédiment était mis en suspension à l'aide d'un mixer avec un poids égal d'une solution aqueuse de glycérine (50 p. 100, $\mathrm{p} / \mathrm{p}$ ), comme cela est indiqué par Accolas \& Auclair [5]. Dans le cas de $L$. helveticus 303 du lait écrémé reconstitué autoclavé était utilisé à la place de la solution de glycérine, car des essais préalables nous avaient montré des pertes relativement importantes d'activité chez les lactobacilles maintenus $24 \mathrm{~h}$ à $-30^{\circ} \mathrm{C}$ quand la solution aqueuse de glycérine était utilisée. La préparation de la suspension concentrée était faite à l'aide de matériel stérilisé préalablement refroidi, le lait reconstitué autoclavé et la solution de glycérine étant à une température comprise entre 3 et $5^{\circ} \mathrm{C}$. Les suspensions ainsi préparées étaient réparties soit dans des tubes d'aluminium à vis, à raison de $25 \mathrm{~g}$ par tube dans le cas de $L$. helveticus 303 , soit dans des flacons en verre jaune à raison de $5 \mathrm{~g}$ par flacon dans le cas des souches de Str. thermophilus. Ces quantités correspondaient aux doses utilisées en fabrication de Gruyère. La préparation de la suspension concentrée et le conditionnement duraient entre 15 et $45 \mathrm{mn}$. Aussitôt après leur conditionnement, les tubes et les flacons étaient placés dans un congélateur réglé à $-30^{\circ} \mathrm{C}$. 


\section{4) Conservation des suspensions concentrées et congelées} pendant le transport et au cours du séjour à la fromagerie.

Les suspensions concentrées étaient conservées dans un congélateur réglé à $-30^{\circ} \mathrm{C}$, pendant des périodes variables (8 jours à 1 mois environ) déterminées surtout par le rythme de leur préparation. Ensuite, elles étaient expédiées à la Station Expérimentale Laitière de Poligny (Jura) dans un récipient calorifugé contenant de la glace carbonique. Le transport durait moins de $24 \mathrm{~h}$ et, à la réception, les tubes et les flacons étaient de nouveau placés dans un congélateur à $-30^{\circ} \mathrm{C}$. Ces suspensions étaient enfin replacées dans la glace carbonique, distribuées et conservées ainsi (de 1 à 7 jours) dans chaque fromagerie jusqu'à leur emploi (1).

\section{5) Epreuve d'activité.}

L'activité des suspensions concentrées et congelées était déterminée à l'aide d'une épreuve analogue à celle utilisée couramment pour la mesure de l'activité des levains [6].

La technique était la suivante : on préparait du lait reconstitué écrémé (100 g de poudre dans 11 d'eau distillée) que l'on autoclavait pendant $10 \mathrm{mn}$ à $110^{\circ} \mathrm{C}$. Dans ce lait, préalablement refroidi et maintenu dans l'eau glacée pendant toute la durée des manipulations, des dilutions décimales étaient faites dans des tubes à vis $(18 \times 130 \mathrm{~mm})$, à partir de $1 \mathrm{~g}$ de l'échantillon à étudier. Les dilutions finales étaient les suivantes : les suspensions concentrées et congelées de $L$. helveticus 303 étaient diluées au 1/1 000 et celles préparées à partir des souches de Str. thermophilus au 1/10 000. Les tubes contenant $15 \mathrm{ml}$ de lait ensemencé étaient incubés dans un bain-marie réglé à $42^{\circ} \mathrm{C} \pm 0,5^{\circ} \mathrm{C}$, pendant $4,5 \mathrm{~h}$, puis refroidis par immersion dans l'eau glacée. L'acidité titrable était déterminée sur $9 \mathrm{~g}$ de ces cultures, avec une solution décinormale de soude en présence de $0,5 \mathrm{ml}$ de phénolphtaléine à 1 p. 100 dans l'alcool à 95 p. 100 . L'activité était exprimée en dg d'acide lactique par 1 (degrés Dornic). Les épreuves étaient faites en double.

Pour effectuer l'épreuve d'activité, les suspensions étaient rapidement décongelées, par immersion, dans un bain-marie réglé à $42^{\circ} \mathrm{C}$, avec agitation constante.

Les valeurs des activités concernant les suspensions concentrées et congelées présentées dans les résultats ont été déterminées à partir de suspensions concentrées conservées pendant 1 à 5 jours à - $30^{\circ} \mathrm{C}$. Quelques essais nous ont montré des variations de l'ordre de 10 p. 100 entre l'activité avant congélation et l'activité après $24 \mathrm{~h}$ de conservation à $-30^{\circ} \mathrm{C}$. Mais ensuite, pendant les premiers jours de conservation à $-30^{\circ} \mathrm{C}$, la variation de l'activité était négligeable. C'est pourquoi, sauf indication contraire, toutes les déterminations d'activité ont été faites à l'intérieur de cette période de 5 jours. 
TABLEAU IV

ConsomMation DE SOUDE 5N, RENDEMENT, ACTIVITÉ ET NOMBRE DE GERMES VIABLES DES SUSPENSIONS CONCENTRÉES CONGELEES OBTENUES PAR CULTURE A $p H$ CONSTANT

\begin{tabular}{|c|c|c|c|c|c|}
\hline \multicolumn{2}{|c|}{ Conditions de culture } & & & \multicolumn{2}{|c|}{$\begin{array}{l}\text { Suspension concentrée } \\
\text { congelée }\end{array}$} \\
\hline Milieux & $\begin{array}{c}\text { Tempé- } \\
\text { rature : } \\
3 \% \circ C \\
p \mathrm{H}\end{array}$ & $\begin{array}{c}\mathrm{NaOH} 5 \mathrm{~N} \\
\text { ajoutée } \\
\text { (1) }\end{array}$ & $\begin{array}{c}\text { Rendement } \\
\text { (2) }\end{array}$ & $\begin{array}{c}\text { Activité } \\
\text { (3) }\end{array}$ & $\begin{array}{c}\text { Nombre } \\
\text { de germes } \\
\text { viables } \\
\text { (4) }\end{array}$ \\
\hline
\end{tabular}

L. helveticus 303

\begin{tabular}{|c|c|c|c|c|c|}
\hline B & 5,0 & $\begin{array}{l}113,6 * \\
14,3 * * \\
21 * * *\end{array}$ & $\begin{array}{r}32,0 \\
6,7 \\
23\end{array}$ & $\begin{array}{l}71,9 \\
7,0 \\
33\end{array}$ & $\frac{2,5}{3}$ \\
\hline A & 5,0 & $\begin{array}{c}115,3 \\
5 \\
9\end{array}$ & $\begin{array}{l}23 \\
6,7 \\
9\end{array}$ & $\begin{array}{c}81,7 \\
2,3 \\
9\end{array}$ & $\begin{array}{l}4,08 \\
1,5 \\
11\end{array}$ \\
\hline B & 6,0 & $\begin{array}{c}136,7 \\
13,8 \\
11\end{array}$ & $\begin{array}{c}33,6 \\
4,9 \\
11\end{array}$ & $\begin{array}{l}68 \\
4,9 \\
11\end{array}$ & $\begin{array}{l}3,02 \\
1,4 \\
14\end{array}$ \\
\hline
\end{tabular}

Str. thermophilus 302

\begin{tabular}{|c|c|c|c|c|c|}
\hline A & 6,5 & $\begin{array}{c}78 \\
8,0 \\
31\end{array}$ & $\begin{array}{r}18,2 \\
2,2 \\
28\end{array}$ & $\begin{array}{c}38,9 \\
3,3 \\
28\end{array}$ & $\begin{array}{l}3,9 \\
1,3 \\
7\end{array}$ \\
\hline
\end{tabular}

(1) Exprimée en $\mathrm{ml}$ de $\mathrm{NaOH} 5 \mathrm{~N}$ par 1 de milieu initial.

(2) Exprimé en $g$ de sédiment bactérien récolté par 1 de milieu de culture initial.

(3) Exprimée en degrés Dornic.

(4) Les chiffres de cette colonne multipliés par $10^{10}$ indiquent le nombre de germes viables par $\mathrm{g}$ de suspension.

* Moyenne.

** Ecart type.

*** Nombre d'essais. 


\section{6) Détermination du nombre de germes viables.}

La détermination du nombre de germes viables des suspensions de $L$. helveticus et de Str. thermophilus, était faite sur milieu gélosé d'Elliker [7]. Les dilutions décimales étaient préparées à partir de $1 \mathrm{~g}$ de suspension dans l'eau peptonée (peptone "Difco " $1 \mathrm{~g}$, eau distillée 1 1). Les boîtes de Petri étaient incubées à $37^{\circ} \mathrm{C}$ pendant $48 \mathrm{~h}$ et on comptait le nombre de colonies qui s'étaient développées.

\section{Résultats}

Les essais préliminaires nous ont montré que les souches de Str. thermophilus se développaient mieux dans les milieux à base de lait digéré par la papaïne sans "corn steep " (milieu A), alors que $L$. helveticus 303 se développait aussi bien dans le milieu A que dans le milieu B.

Ces milieux ont été mis au point en tenant compte des nombreux travaux concernant la culture des bactéries lactiques, notamment ceux qui ont porté sur l'utilisation du lait digéré par la papaïne [8] comme milieu de culture et ceux relatifs à l'effet stimulant du "corn steep " [9] et du manganèse [10] sur la croissance des bactéries lactiques. Ces milieux sont d'un prix de revient modéré : $0,35 \mathrm{~F}$ le 1 environ; toutefois, ce prix tient compte seulement du prix des produits nécessaires à la préparation des milieux. La technique de préparation est simple et peut se prêter à une fabrication industrielle. Un chauffage au-dessous de $100^{\circ} \mathrm{C}$ suffit pour insolubiliser les substances précipitables par la chaleur et cela constitue un avantage non négligeable en vue de la préparation à grande échelle.

Ces milieux ont une légère turbidité due à des substances colloïdales difficiles à séparer dans les conditions de centrifugation utilisées.

Le tableau IV montre les résultats concernant l'activité, le rendement et le nombre de germes viables des suspensions concentrées de $L$. helveticus 303 et de Str. thermophilus 302 ainsi que des données relatives à leur préparation.

Les souches de Str. thermophilus 21,160 et 310 ont donné des rendements et des activités du même ordre que la souche 302.

Le nombre de germes viables (capables de former une colonie sur la gélose nutritive) a été déterminé sur des suspensions après différentes périodes de conservation à $-30^{\circ} \mathrm{C}$. Il est du même ordre pour les suspensions de $L$. helveticus 303 et celles de Str. thermophitus 302.

Les suspensions de $L$. helveticus 303 contiennent environ 10 fois plus de germes viables par g que les cultures sur lait autoclavé de la même souche, pour lesquelles la moyenne est de l'ordre de 
$2 \times 10^{9}$. Pour Str. thermophilus 302 , les suspensions sont environ 60 fois plus riches en germes viables que les cultures correspondantes sur lait autoclavé, lesquelles contiennent en moyenne $6 \times 10^{8}$ par $\mathrm{g}$.

Le tableau IV montre également la consommation de soude et le rendement en sédiment bactérien. On peut estimer que pour préparer $1 \mathrm{~kg}$ de suspension de bactéries lactiques thermophiles, il faut, dans le cas de $L$. helveticus 303 , cultivé à $p H \quad 6,0$ dans le milieu A, 14,8 1 de milieu de culture et 21 de soude $5 \mathrm{~N}$, auxquels s'ajoutent $0,5 \mathrm{~kg}$ de lait écrémé. Pour Str. thermophilus 302 , dans le milieu à $p \mathrm{H} 6,5$, il faut $26 \mathrm{l}$ de milieu de culture, $2 \mathrm{l}$ de soude $5 \mathrm{~N}$ et $0,5 \mathrm{~kg}$ de la solution aqueuse de glycérine 50 p. 100 .

A partir de ces données, nous avons calculé le prix de revient d'un $\mathrm{kg}$ de suspension concentrée congelée, comme le montre à titre indicatif, le tableau $\mathrm{V}$; ces prix sont établis en tenant compte uniquement des composants nécessaires à l'obtention des suspensions.

Nous devons finalement signaler que nous avons rencontré les mêmes inconvénients, remarqués par Accolas \& Auclair [5] chez certaines souches de streptocoques mésophiles, dans le cas de la souche de Str. thermophilus SCH cultivée à $p \mathrm{H}$ constant. En effet, il a été impossible d'obtenir une séparation convenable des cellules lors de la centrifugation.

\section{TABLEAU V}

Prix de revient approximatif de $1 \mathrm{KG}$ de suspension Concentrée congelée DE BACTÉRIES LACTIQUES THERMOPHILES

\begin{tabular}{|c|c|c|}
\hline 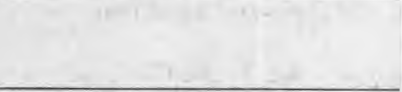 & L. helveticus 303 & Str. thermophilus 302 \\
\hline $\begin{array}{l}\text { Milieu de culture } \ldots \ldots \ldots \ldots \\
\text { NaOH } 5 \mathrm{~N}(1) \ldots \ldots \ldots \ldots \ldots \\
\text { Lait reconstitué écrémé (2) } \\
\text { Glycérine pure (3) } \ldots \ldots \ldots \ldots\end{array}$ & $\begin{array}{r}14,81 \times 0,35 \mathrm{~F}=5,18 \mathrm{~F} \\
2,01 \times 2,58 \mathrm{~F}=5,16 \mathrm{~F} \\
0,5 \mathrm{~kg} \times 0,41 \mathrm{~F}=0,20 \mathrm{~F} \\
-\end{array}$ & $\begin{array}{r}26,01 \times 0,35 \mathrm{~F}=9,10 \mathrm{~F} \\
2,01 \times 2,58 \mathrm{~F}=5,16 \mathrm{~F} \\
\overline{0}, 25 \mathrm{~kg} \times 9,0 \mathrm{~F}=2,25 \mathrm{~F}\end{array}$ \\
\hline 19. & $10,56 \mathrm{~F}$ & $16,51 \mathrm{~F}$ \\
\hline
\end{tabular}

(1) Prix calculé à partir de la lessive de soude pure $\mathrm{D}=1,33$.

(2) Pour obtenir $1 \mathrm{~kg}$ de suspension, il faut $0,5 \mathrm{~kg}$ de lait pour $0,5 \mathrm{~kg}$ de sédiment bactérien. (Lait reconstitué à raison de $100 \mathrm{~g}$ de poudre dans 11 d'eau.)

(3) $1 \mathrm{~kg}$ de suspension est obtenu à partir de $0,5 \mathrm{~kg}$ de sédiment $+0,5 \mathrm{~kg}$ d'une solution aqueuse de glycérine à 50 p. 100 . 


\section{Discussion}

Les suspensions concentrées et congelées utilisées dans les fabrications de Gruyère (1) ont d'abord été préparées pour $L$. helveticus 303 avec le milieu $\mathrm{B}$ à $p \mathrm{H}$ 5,0 et pour Str. thermophilus 302, avec le milieu $\mathrm{A}$ à $p \mathrm{H}$ 6,5.

Nous avons éprouvé des difficultés pour la séparation des lactobacilles à partir du milieu $\mathrm{B}$ à $p H \quad 5,0(*)$, ce qui nous a conduit finalement à adopter le milieu A (de préparation plus facile) à $p H$ 6,0 pour l'obtention des suspensions de $L$. helveticus 303 . Dans ces conditions, les opérations de centrifugation (débit et efficacité de séparation des bactéries) sont nettement meilleures.

II ressort des premiers résultats qu'il est possible de préparer des suspensions concentrées et congelées de bactéries lactiques thermophiles suffisamment actives, pour être utilisées directement dans les fabrications de Gruyère. La technique de préparation est relativement simple et susceptible d'être adaptée à l'échelle industrielle. Toutefois, des améliorations doivent être réalisées en ce qui concerne la séparation des bactéries au moyen de la centrifugation : cette opération risque de poser des problèmes d'équipement très importants, si l'on tient compte des débits relativement faibles observés en travaillant à petite échelle.

Nous n'avons pas fait une étude systématique de la variation de l'activité des suspensions concentrées et congelées en fonction du temps de conservation à $-30^{\circ} \mathrm{C}$. Nous nous sommes bornés à contrôler d'une part, la variation de l'activité après conservation des suspensions d'abord congelées à $-30^{\circ} \mathrm{C}$ pendant 8 jours dans la glace carbonique et, d'autre part, après 2 mois de conservation à $-30^{\circ} \mathrm{C}$ (date limite que nous avions fixée pour l'utilisation en fromagerie). Dans ces deux cas, les premiers résultats concernant l'utilisation en fromagerie ont montré que l'activité n'était pas affectée.

Des contrôles sporadiques nous ont révélé par ailleurs des très faibles pertes d'activité après 8 mois de conservation dans le cas de $L$. helveticus 303 et après 11 mois, dans le cas de Str. thermophilus 302.

En nous basant sur un certain nombre d'essais préliminaires en fromagerie, nous avons utilisé dans les fabrications de Gruyère, $100 \mathrm{~g}$ d'une suspension concentrée et congelée de $L$. helveticus 303 et $10 \mathrm{~g}$ d'une suspension de Str. thermophilus 302 pour 10001 de lait. Ces doses représentent une réduction d'environ 10 à 100 fois respectivement, des doses de levain sur lait autoclavé utilisées en fabrication de Gruyère. Elles devront faire l'objet d'une détermination plus précise dans des essais ultérieurs.

(*) Et également avec le milieu A à $p H$ H, 5 . 
La diffusion de ce nouveau procédé d'utilisation en fromagerie des bactéries lactiques thermophiles exigera en effet, des mises au point, concernant par exemple, l'obtention de suspensions plus actives (permettant de réduire les quantités utilisées, notamment en ce qui concerne les lactobacilles) et la préparation de suspensions contenant à la fois $L$. helveticus et Str. thermophilus dans la même " dose ".

Ce sont là des améliorations nécessaires pour que cette nouvelle technique soit réellement bien adaptée à la préparation de suspensions à grande échelle et pour qu'elle puisse être adoptée par les praticiens.

D'autre part, d'après les premières évaluations, le prix de revient des suspensions concentrées et congelées de bactéries lactiques thermophiles, ainsi que leur transport et leur distribution, ne semble pas constituer un obstacle majeur à leur extension dans la pratique.

\section{Résumé}

A l'aide de milieux de culture d'un faible prix de revient, des suspensions concentrées et congelées de bactéries lactiques thermophiles ( $L$. helveticus et Str. thermophilus) destinées à la fromagerie de Gruyère, ont été préparées comme suit : culture à $p H$ constant, centrifugation, mise en suspension du sédiment bactérien soit dans du lait écrémé ( $L$. helveticus) soit dans une solution aqueuse de glycérine (Str. thermophilus) et congélation à $-30^{\circ} \mathrm{C}$.

Ces suspensions concentrées et congelées renfermant de 1 à $4 \times 10^{10}$ germes viables par $\mathrm{g}$ n'ont pas montré de perte d'activité après 8 jours de conservation dans la glace carbonique, ni après 2 mois de conservation à $-30^{\circ} \mathrm{C}$. Elles ont été utilisées directement pour la fabrication de Gruyère de Comté à raison de $100 \mathrm{~g}(L$. helveticus) et de $10 \mathrm{~g}$ (Str. thermophilus) pour 10001 de lait.

Le mode de préparation du milieu de culture ainsi que la technique de préparation de ces suspensions sont décrits.

Le rendement des préparations, l'activité et le nombre de germes viables après congélation ont été étudiés. Le prix de revient approximatif de ces suspensions a été calculé.

Reçu pour publication le 6 septembre 1968.

\section{Summary}

Preparation of concentrated frozen suspensions of thermophilic lactic acid bacteria for use in cheese making.

Using a low cost culture medium, concentrated frozen suspension of thermophilic lactic acid bacteria ( $L$. helveticus and 
Str. thermophilus) have been prepared for use in Gruyère cheesemaking. The lactic acid bacteria were cultivated at a constant $p H$ during a suitable time, then centrifuged and the sediment was suspended either in skim milk ( $L$. helveticus) or in a glycerol solution (Str. thermophilus). The suspensions were frozen at $-30^{\circ} \mathrm{C}$.

The concentrated frozen suspensions contained 1 to $4 \times 10^{10}$ viable organisms per $\mathrm{ml}$; they did not show any loss of activity after storage in dry ice for 8 days, neither after storage for 2 months at $-30^{\circ} \mathrm{C}$.

They were used directly for making "Gruyère de Comté " cheese at the rate of $100 \mathrm{~g}$ (L. helveticus) and $10 \mathrm{~g}$ (Str. thermophilus) per 10001 of milk.

The yield, activity and viability of the suspensions after freezing have been studied. An estimate of cost of preparation of these suspension has been calculated.

Nous remercions MM. Auclair, Mourgues et Vassal pour les conseils qu'ils ont bien voulu nous apporter au cours de ce travail et de la rédaction du manuscrit.

\section{BIBLIOGRAPHIE}

[1] Rousseaux (P.), Vassal (L.), Valles (E.), Auclair (J.) \& MocQUOT (G.). Utilisation en fromagerie de suspensions concentrées et congelées de bactéries lactiques thermophiles. Le Lait, 48, 241-254, 1968.

[2] LAMPRECH (E. D.) \& Foster (E. M.). The survival of starter organisms in concentrated suspensions. J. appl. Bact., 26, 359-369, 1963.

[3] Bergìre (J.-L.). Production massive de cellules de streptocoques lactiques. I. Méthodes générales d'étude et facteurs de la croissance de Str. lactis C 10. Le Lait, 48, 1-11, 1968.

[4] Bergère (J.-L.) \& Hermier (J.). Production massive de cellules de streptocoques lactiques. II. Croissance de Streptococcus lactis en milieu à $p \mathrm{H}$ constant. Le Lait, 48, 13-30, 1968.

[5] Accolas (J.-P.) \& Auclair (J.). Conservation à l'état congelé de suspensions de bactéries lactiques concentrées sous faible volume. I. Bactéries lactiques mésophiles. Le Lait, 47, 253-260, 1967.

[6] Golding (N.S.) \& MCCorkle (L.). Starter activity test. $X I I^{\mathrm{e}}$ Cong. Intern. de Laiterie, La Haye, tome III, 1209-1215, 1953.

[7] Elliker (P. R.), Anderson (A. W.) \& Hanneson (G.). An agar medium for lactic acid streptococci and lactobacilli. J. Dairy Sci., 39, 1611$1612,1956$.

[8] Guittonneau (G.) \& Chevalier (R.). Nouvelles techniques de préparation d'un milieu de culture à base de lait digéré. Le Lait, 20, $1-8,1941$.

[9] Kannedy (H. E.) \& Speck (M. L.). Studies on corn steep liquor in nutrition of certain lactic acid bacteria. $J$. Dairy Sci., 38, 208-216, 1955.

[10] Stamer (J. R.), Albury (M. N.) \& Pederson (C. S.). Substitution of manganese for tomato juice in cultivation of lactic acid bacteria. Appl. Mierobiol., 12, 165-168, 1964. 